\section{Kastamonu Eğitim Dergisi Kastamonu Education Journal}

Kastamonu 2019 Cilt:27 Sayı:6

kefdergi.kastamonu.edu.tr
Başvuru Tarihi/Received: 05.12.2018

Kabul Tarihi/Accepted: 07.02.2019

DOI: $10.24106 /$ kefdergi.3459

\title{
Sesbilgisel Farkındalık Becerilerini Desteklemeye Yönelik SESFAR Müdahale Programının Etkililiğinin İncelenmesi
}

\section{The Investigating of Effectiveness of the SESFAR Intervention Program Aimed Supporting at Phonological Awareness Skills}

\author{
Deniz AKDAL', Tevhide KARGIN²
}

\section{Öz}

Bu araştırmada sesbilgisel farkındalık becerilerine yönelik geliştirilen SESFAR müdahale programının, zayıf sesbilgisel farkındalık becerilerine sahip olan 5 yaş grubu çocukları üzerindeki etkisinin incelenmesi amaçlanmaktadır. Zayıf sesbilgisel farkındalık becerilerine yönelik hazırlanan müdahale programının içeriğini sözcükleri hecelerine ayırma, heceleri birleştirme, cümleyi sözcüklere ayırma, uyak farkındalığı, ilk sese göre eşleştirme, son sese göre eşleştirme, sözcüklerin ilk sesini atma ve sözcüklerin son sesini atma becerilerini destekleyen 8 beceri alanını kapsayan ve her bir beceriye ait 9 etkinlik bulunan toplam 72 etkinlik ve 595 adet görsel oluşturmaktadır. SESFAR müdahale programı modüler programlama yaklaşımı kullanılarak hazırlanmış ve doğrudan öğretim yöntemi aşamalarına göre uygulanmıştır. Araştırmada gözlemciler arası güvenirlik ve uygulama güvenirliği verileri analiz edilmiş ve yüksek güvenirlik bulguları elde edilmiştir. Araştırma bulgularında; gruplar arası karşılaştırmalarda Mann Whitney $U$ testi kullanılmış olup deney ve kontrol grubunun sontest puanları arasında istatistiksel olarak anlamlı fark olduğu belirlenmiştir. Sonuç olarak uygulanan SESFAR müdahale programının zayıf sesbilgisel farkındalık becerilerine sahip çocuklar üzerinde etkili olduğunu göstermektedir.

Anahtar Kelimeler: erken okuryazarlık, sesbilgisel farkındalık, SESFAR müdahale programı

\section{Abstract}

The aim of this study is to investigate the impact of the SESFAR intervention program towards phonological awareness skills on 5-year-old children with weak phonological awareness skills. The content of the intervention program designed for weak phonological awareness skills includes 8 skill areas that support the ability to segmenting words into syllables, syllable blending, rhyming, match the first sound, match the last sound, throw the first sound of words and throw the last sound of words out and 9 activities for each skill, totally 72 activities and 595 illustrations.SESFAR intervention program was prepared by using modular programming approach and was applied according to direct teaching method steps. Inter-observer reliability and application reliability data were analyzed in the study and high reliability findings were obtained. In the research findings; Mann Whitney $U$ test was used in the comparisons between the groups and it was determined that there was a statistically significant difference between the posttest scores of the experimental and control groups. Consequently, SESFAR intervention program is effective on children with weak phonetic awareness skills.

Keywords: early literacy, phonological awareness, SESFAR intervention program 


\section{Extended Abstract}

Introduction: The purpose of this research is to review the impact of SESFAR (phonological awareness intervention program) intervention program, which has been developed for improving phonological awareness skills, on 5-year-old children with low phonological awareness skills.

Method: The study was designed as random pattern model with pretest-posttest control group, which is one of the actual experimental design. Phonetic awareness dimension of early literacy test developed for per-school children has been applied to 157 children; 20 children, who were randomly selected among 42 children who have got lower score than the threshold, were randomly selected, constituted the workgroup of the study. The intervention program prepared for low phonological awareness skills consists of 8 skill areas that support the following skills: segmenting words into syllables, combining syllables, segmenting sentences into words, rhyme awareness, matching first phoneme, matching last phoneme, deleting fist phoneme of the word and deleting last phoneme of the word. There are 9 activities for each skill, so it contains a total of 72 activities and 595 visuals. SESFAR intervention program has been developed using modular programming approach and it was executed in accordance with the stages of direct instruction. Interrater reliability and intervention reliability of the research were checked and high reliability outcomes were obtained.

Results: Regarding the findings of the research: Mann Whitney $U$ test was used to compare the groups. It was found that there is a significant difference between posttest scores of test and control groups, which shows that SESFAR intervention program is effective on the children with low phonological awareness skills. Wilcoxon signed ranks test was used for the comparison within the group. Accordingly, it was found that there is a significant difference between pretest and posttest scores of the test group, however such a difference was not observed in the control group. This finding shows that SESFAR intervention program that supports weak phonological awareness skills has improved phonological awareness skills of the children in the test group.

Discussion and Conclusion: As a consequence, considering all the information proffered above, it is obvious that SESFAR is an instrumental program to support the phonological awareness skills of children who need support in their phonological awareness skills. When taken into consideration in terms of content and extent, SESFAR has the distinction of being the first and most comprehensive intervention program on this subject in Turkey. Concurrently, it is practical, cost-effective, easy to carry and understandable. As this regard, it is expected to fill a major gap in the area for teaching early literacy skills, provide the support what teachers need for teaching the subject and be an important starting point for the promotion of early literacy skills in Turkey. 


\section{Giriş}

Okuma becerisi bireylerin akademik becerileri kazanmalarında bir ön koşul niteliği taşımaktadır. Başarılı bir okuma etkinliğini okuyucuların yazılı metinlerde yer alan kelimeleri uygun ortografik, sesbilgisel, morfolojik bilgi ve becerilerini kullanarak çözümledikleri, ardından çözümlenen kelimeleri var olan sözcük dağarcıkları, önceki bilgi ve deneyimleri ile bağdaştırarak anlamlandırdıkları, sonrasında ise anlamlandırdıkları kelimelerden oluşan cümleleri sözdizimsel özellikleri bağlamında analiz edip verilmek istenen mesaja ulaşabildikleri bir süreç olarak tanımlamak mümkündür (Güldenoğlu, Kargın ve Miller, 2015). Yapılan araştırmalar erken okuryazarlık becerilerine sahip olan çocukların okuma becerisinde başarılı olduğunu göstermektedir (Apel ve Lawrence, 2011; Konza, 2011). Bu bağlamda erken okuryazarlık becerileri içerisinde önemli bir beceri olarak görülen sesbilgisel farkındalık becerisinin (Schatschneider, Francis, Foorman, Fletcher ve Mehta, 1999) gelişimi okuma ve yazma öğreniminde önemli bir öncüldür ve okuma-yazma becerilerini edinmede güçlük yaşamak sesbilgisel farkındalık becerilerinin performansları ile yakından ilişkilidir (Fox, Reilly ve Blumstein, 2015).

Sesbilgisel farkındalık çocuğun, cümlelerin kelimelerden oluştuğunu, kelimeleri oluşturan seslerin birbirleri ile farklılıklarını, kelimelerin söylenişlerinin benzer olabileceğini, kelimelerin ilk seslerinin aynı sesle başlayabileceğini, kelimelerin son seslerinin aynı sesle bitebileceğini, kelimelerin ortalarındaki seslerin aynı olabileceğini, kelimelerin sesbirimlerine ayrılabileceğini, ses birimlerini birleştirerek kelimeler üretebilmeyi ve kelimelerden bazı hece veya sesler çıkarıldığında yeni kelimeler oluşabileceğini fark edebilmesini kapsamaktadır (Bennett-Armistead, Duke ve Moses, 2005). Bununla birlikte sesbilgisel farkındalık, sadece kelimelerle ilgili bir süreç değildir; aynı zamanda kelimenin ve anlamının ötesinde odaklanılan nokta, kelimenin ses yapısına ait becerileri kapsamaktadır (Karaman, 2013). Sesbilgisel farkındalık becerilerinin edinim aşamaları ve sırası da alanyazında önemli bir yer tutmaktadır. Sesbilgisel farkındalık becerilerini oluşturan uyak farkındalığı, kelime farkındalığı, hece farkındalığı ve sesbirimsel farkındalık becerileri ayrı ayrı ele alınmıştır.

\section{Uyak farkındalığı}

Söylenişleri benzer olan kelimeleri fark etme yeteneği (Konza, 2011) ve hece sonu birimlerine dayanan bir sesbilgisel farkındalık biçimi (Treiman, 1992) olarak tanımlanmıştır. Uyak farkındalığı bulunan sözcükler üretmek ise söylenişleri benzer olan kelimeler üretme yeteneğidir (Konza, 2011). Farklı başlangıç sesleri olan ancak vurgulanan ünlünün ve onu izleyen seslerin aynı olduğu kelimelerden oluşmaktadır (ör. kat, yat, tat). Çocuklar daha iki yaşındayken uyak farkındalığı ve ses oyunlarındaki sesleri anladıklarını göstermeye başlar (Owens, 2005). Lane, Pullen, Eisele ve Jourdan (2002) çocukların doğuştan uyaklı sözcükleri tanıma yeteneğine sahip olmadığını, büyüdükçe çevresindeki konuşulan dil ile karşılaştıkça uyak farkındalığı becerilerinin geliştiğini belirtmişlerdir. Fakat risk grubunda bulunan çocukların bu doğal süreçte uyak farkındalığı becerilerinde zayıf performans sergiledikleri, söylenişleri benzer olan ve olmayan kelimelerin tespitinde zorluk yaşadıkları ve eğitime ihtiyaç duydukları ifade edilmiştir (Lovelace, 2008).

\section{Kelime Farkındalığı}

Kelime farkındalığı becerisini çocuklar yavaş yavaş konuşmanın kelimelerden oluştuğunun farkına vararak edinirler. Örneğin, konuşmaya yeni başlayanlar "hepsi bitti" veya "teşekkür ederim"i tek bir kelime gibi düşünür (Scott, 2009). Söylenişleri benzer olan kelimeleri bulma 3 yaş civarında, söylenişleri benzer olan kelimeler üretme becerisi ise 3 - 5 yaş arasında ortaya çıkar (Andreassen ve Simpson, 2008; Johnson ve Roseman, 2003; Paul, 2007).

\section{Hece Farkındalığı}

Bir kelimede yer alan heceleri belirleme ve hece sayısını tespit etme yeteneğidir (Mann ve Liberman, 1984). Hece farkındalığı becerisi 3-4 yaşları arasında kazanılır ve sözlü dil kullanımı bu becerilerin gelişimine katkıda bulunur (Daniel ve Reynolds, 2007). Bu beceri çocuk bir kelimedeki hece sayısını tespit edebildiği zaman ortaya çıkar (Daniel ve Reynolds, 2007).

\section{Sesbirimsel farkındalık}

Sesbilgisel farkındalık becerilerinin genel gelişimine benzer bir şekilde, hiyerarşik bir yolla gelişir. Sesbirimsel farkındalığın dört ana alt-becerisi; sesleri tespit etme, sesleri birleştirme, sesleri parçalara ayırma ve sesleri değiştirmedir (Konza, 2011). Sesbirimsel farkındalık sırasındaki ilk edinilen beceri sesleri tespit etmedir. Bu aşamada, bir çocuk bir kelimenin başındaki, ortasındaki ve sonundaki sesleri tespit edebilir (Daniel ve Reynolds, 2007). Sesleri birleştirme, sesbirimsel farkındalık becerileri arasında kazanılan ikinci beceridir ve 5-6 yaşlarında edinilir. Seslerin birleştirilmesi çocuğun farklı sesleri dinlemesini ve daha sonra bunları bir kelimede bir araya getirmesini gerektirir. Çocuk bu aşamaya, 
kelimelerle başlar ("kat" kelimesi gibi) ve daha sonra bunu tekil seslere (/k/, /a/, /t/) ayırarak becerinin karmaşıklığını arttırır (Konza, 2011). Sesbirimsel farkındalık becerilerinin kazanım sırasındaki üçüncü beceri sesleri parçalara ayırmadır. Bu beceri 6-7 yaşlarında kazanılır. Sesleri parçalara ayırma kelimelerin içindeki tekil sesleri sayma ve kelime üretme yeteneğidir (Daniel ve Reynolds, 2007; Konza, 2011). Bu beceriyi test etmek için çocuğa "... kelimesinde kaç ses duyuyorsun?" sorusu yöneltilir (Konza, 2011). Dördüncü sıradaki beceri ise ses değiştirme becerisidir. Bu beceri sesbirimsel farkındalığın en karmaşık becerisidir ve 6-7 yaşlarında kazanılır (Daniel ve Reynolds, 2007; Konza, 2011). Ses değiştirme becerisi çocuğun kendisine sunulan kelimeye ses ekleyerek, ses çıkartarak veya sesin yerine başka bir ses koyarak farklı kelimeler oluşturmasını gerektirir (Konza, 2011). Örneğin, çocuk "tat" kelimesini alıp, /t/ sesini atıp, yerine /k/ sesi koyarak "kat" kelimesini üretme yeteneğine sahip olacaktır (Romero, 2015). Sesbirimsel farkındalık becerileri gelişimlerinin yaşla yakın ilişki içerisinde olduğu görülmektedir.

Normal gelişim gösteren çocuklarda sesbilgisel farkındalık becerileri ileriki dönem okuma ve heceleme becerilerinin yordayıcısı olduğu ve bu becerilerde zorlanan çocukların çoğunlukla okuma ve heceleme becerilerinde düşük performans sergiledikleri gösterilmiştir (Jenkins ve Bowen 1994; Roth, Troia, Worting ve Handy, 2006). Pek çok araştrrmada, sesbilgisel farkındalık becerilerinin daha sonraki okuma başarısında önemli olduğu (Adams, 1990; Snow, Burns ve Griffin, 1998; National Reading Panel, 2000; Nielsen ve Luetke-Stahlman, 2002) ve okulöncesi çağındaki çocukların sesbilgisel farkındalık becerileri ilerideki okuma başarısının güçlü bir yordayıcısı (Bradley ve Bryant, 1983; Lundberg, Olofsson ve Wall, 1980; Torgeson, Wagner ve Rashotte 1994) olduğu bulunmuştur. Bu durum okuma sorunu olan çocukların sesbilgisel farkındalığa ait stratejileri yeterli derecede kullanamamaları ve bu stratejilerin kazanamamaları ile sesbilgisel işlemlerdeki yetersizlikler ile açıklanmaktadır. Sesbilgisel farkındalık becerilerinin, okuma başarısının yordayıcısı olması nedeniyle, sesbilgisel işlemlere yönelik becerilere müdahale edilmesi okuma gelişimini olumlu olarak etkileyecektir (Yücel, 2009). Erken dönemde, sesbilgisel farkındalık alanında uygulanan müdahale programları okuma ve yazma alanlarında başarısız olmayı engelleyerek okul başarısını güçlendirecektir (Ferraz, Pocinho, Pereira ve Pimenta, 2015). Okuma becerilerinin edinimini ve ilerideki okuma başarısını yakından ilgilendiren sesbilgisel farkındalık becerilerine yönelik müdahale programının gerekliliği özellikle risk grubundaki çocuklar düşünüldüğünde önemli bir konu olarak karşımıza çıkmaktadır. Tüm bu beceriler birlikte düşünüldüğünde sesbilgisel farkındalık becerileri zayıf olan çocuklar ilerleyen yaşlarda okuma ve akademik becerilerin ediniminde zorlanmaktadırlar. Bu tarz çocukların uygun yaş grubunda tespit edilerek bu becerilere yönelik müdahale programlarının çocuklara uygulanması gerekmektedir. Ülkemizde sesbilgisel farkındalık becerilerine yönelik becerilerin tamamını veya bir kısmını bünyesinde bulunduran bir çalışma olmaması hazırlanmış olan müdahale programımızın önemini arttırmaktadır. Araştırma sürecinde hazırlanmış olan müdahale programının döküman haline getirilmesinin zayıf sesbilgisel farkındalık becerilere sahip çocukların sesbilgisel bilgi ve becerilerinin gelişimi sürecinde kullanabilecektir. Ayrıca alanyazına yeni bir ürünün kazandıracak olması ve bu ürünün uzman kişilere, ailelere ve alanda yapılacak diğer çalışmalara kaynak oluşturacağı gibi bu alanda gereksinim duyulan bir eksikliği gidermesi açısından önemli görülmektedir. Bu nedenlerle bu araştırmanın amacı; Sesbilgisel Farkındalık Becerilerini Desteklemeye Yönelik SESFAR Müdahale Programının, zayıf sesbilgisel farkındalık becerilerine sahip olan 5 yaş grubu çocukları üzerindeki etkililiğini incelemektir.

\section{Yöntem}

\section{Araşttrma Modeli}

Zayıf Sesbilgisel Farkındalık Becerilerine Yönelik Geliştirilen Müdahale Programının Etkililiğinin incelendiği bu çalışma, Gerçek Deneysel Desenlerden "Öntest - sontest kontrol gruplu seçkisiz desen" modeli niteliğindedir. Uygulanan müdahale yöntemi araştırmanın bağımsız değişkenini oluşturmakta iken sesbilgisel farkındalık becerileri ise bağımsız değişkenini oluşturmaktadır.

\section{SESFAR Müdahale Programı}

Araştırmanın bağımsız değişkeni, Zayıf Sesbilgisel Farkındalık Becerilerini Destekleyen Müdahale Programıdır (SESFAR). SESFAR müdahale programı bir yıl içerisinde hazırlanmış ve asıl uygulama öncesinde pilot uygulaması yapılmıştır. SESFAR, sesbilgisel farkındalık becerilerini (sözcükleri hecelerine ayırma, heceleri birleştirme, cümleyi sözcüklere ayırma, uyak farkındalığı, ilk sese göre eşleştirme, son sese göre eşleştirme, sözcüklerin ilk sesini atma ve sözcüklerin son sesini atma) destekleyen 8 beceri alanını kapsayan ve her bir beceriye ait 9 etkinlik bulunan toplam 72 etkinlikten oluşan bir müdahale programıdır. Etkinlikler çocukların keyifle ve eğlenerek yapacakları oyun kurguları ile oluşturulmuştur. Her beceri için uygulanan ilk etkinlikler çocukların hedeflenen beceriyi anlamasına yönelik oluşturulmuştur. SESFAR müdahale programı sesbilgisel farkındalık becerilerinin kendi içerisindeki büyük birimlerden küçük birimlere doğru bir sıra izleyerek, kolaylık zorluk derecesine dikkat edilerek ve gelişim aşamaları temel alınarak hazırlanmıştır. 
Müdahale programında kullanılan etkinliklerin tamamı araştırmacı tarafindan alanyazın taranarak hazırlanmıştır. Etkinliklerin uygulama aşamasında kullanılmak üzere 595 adet resim grafik tasarımcılar tarafindan çizilmiştir. Resimlerin çocukların gelişimine ve hedeflenen beceriye ait uygunluğu alanında uzman 2 akademisyen, 1 okulöncesi öğretmen ve 1 özel eğitim öğretmeni tarafindan müdahale programının geçerliliği incelenmiştir. Alan uzmanları tarafindan incelen resimlerden 14 resim tekrardan hazırlatımış ve yeni hazırlanmış şekli etkinliklerde kullanılmıştır. SESFAR müdahale etkinliklerinde yer alan görsellerin dışında etkinliklerin yapılabilmesi için etkinliklerle birlikte hazırlanmış olan farklı oyun zeminleri bulunmaktadır. Oyun zeminleri her etkinlik için ayrı ayrı grafik tasarımcılar tarafindan çizdirilmiştir. Müdahale programın hazırlanmasın da program geliştirme uzmanları ile çalışılış ve SESFAR müdahale programı modüler programlama yaklaşımı kullanılarak hazırlanmıştır. Modüler programlama yaklaşımında içerik düzenlenirken konular öbekler halinde düzenlenir. Öğrenme üniteleri modüllere ayrılır. Her modül kendi içerisinde doğrusal, sarmal ya da farklı yaklaşımla düzenlenebilir. Modüller arasında aşamalı bir bağ olması önemli değildir; önemli olan her modülün anlamlı bir bütün oluşturmasıdır (Demirel, 2004).

Müdahale programının uygulama aşamasında ise doğrudan öğretim yöntemi benimsenmiştir. SESFAR müdahale programı etkinliklerinin uygulama planları doğrudan öğretim yöntemine göre hazırlanmış ve uygulama kılavuzunda uygulama yönergeleri verilmiştir. Hazırlanılan 72 etkinliğe ait doğrudan öğretim plan örnekleri alanında uzman iki doktor öğretim üyesi tarafindan incelenmiş ve gerekli düzenlemeler yapılmıştır.

\section{Çalışma Grubu}

Araştırmanın çalışma grubunun belirlenmesinde; bağımsız anaokulları ile ilkokulların bünyesinde bulunan anasınıflarında öğrenim gören, hastaneler ve rehberlik ve araştırma merkezleri tarafindan tanılanmış herhangi bir engeli bulunmayan ve 60-72 ay arası zayıf sesbilgisel farkındalık becerilerine sahip çocuklar oluşturmaktadır. Çalışma grubunun oluşturulmasında amaçsal örnekleme yöntemlerinden tabakalı amaçsal örnekleme stratejisi kullanılmıştır. Zayıf sesbilgisel farkındalık becerisine sahip olan çocukların tespiti aşamasında EROT (Erken Okuryazarlık Testi)'un sesbilgisel farkındalık alt boyutu 157 çocuğa uygulanmış ve zayıf sesbilgisel farkındalık becerilerine sahip olan 42 çocuk arasından rastgele örneklem yöntemi ile araştrrma grubunu oluşturacak olan 20 çocuk belirlenmiştir. Tespit edilen 20 çocuktan $10^{\prime}$ u deney $10^{\prime}$ u kontrol grubu için rastgele belirlenmiştir. Deney grubunu oluşturan çocuklardan denek kaybı olma intimaline karşın yedek olarak belirlenmiş olan 2 çocuk ise araştırmaya hiç dahil edilmemiştir. Araştırmanın deney grubunda yer alan erkek çocuklardan birisi daha önceki dönemlerde kreş eğitimi almışken diğer çocuklar ise herhangi bir eğitim almamışlardır.

\section{Uygulama Süreci}

\section{Pilot Uygulama Süreci}

Pilot uygulama süreci için herhangi bir tanı almamış, normal gelişim gösteren $60-72$ ay arası 5 çocuk belirlenmiştir. Pilot uygulama Kırşehir ilinde özel bir kreşte uygun bir sınıfta hafta içi üç gün hafta sonu bir gün günde üç etkinlik öğretimi düzenlenerek yapılmıştr. Çalışmanın pilot uygulama aşaması hafta içi 17-00 ile 19.30 arasında hafta sonu ise 13.30-16.00 arasında iki hafta boyunca devam etmiştir. Pilot uygulama sürecinin tamamı video kaydına alınmıştr. Her bir etkinlik 25-30 dakika arası sürmüştür. Pilot uygulama sürecinde her bir etkinlik uygulamasından önce ve sonra $15 \mathrm{dk}$ çocuklara birbirleri ile tanışmaları ve oyun oynamaları için serbest zaman bırakılmıştır. Fakat çocukların rahatsızlığından dolayı bazı etkinliklere 3 çocuk bazı etkinliklere ise 4 veya 5 çocuk katıı ımıstır. Pilot çalışmanın yürütüldüğü dönemde çocuklar gün içerisinde okulöncesi eğitim kurumlarına devam etmişlerdir. Pilot uygulama sürecinde çocukların uygulamanın yapılacağı mekana gidiş ve gelişlerinde sınırlılıklar yaşanmıştr. Ek araçlar düzenlenerek bu süreçler düzenlenmiştir.

\section{Ana Uygulama Süreci}

Araşttrmada uygulanacak olan "Sesbilgisel Farkındalık Müdahale Programı" 8 hafta ve haftada 3 oturum olacak şekilde 02/04/2018 tarihinde başlamış 25/05/2018 tarihinde ana uygulama tamamlanmıştır. Her bir oturum 20 dakika sürmüştür. Her bir oturumda 3 etkinlik yapılmış olup 8 hafta boyunca sesbilgisel farkındalık müdahale programında yer alan toplam 72 etkinlik 2 ay boyunca uygulanmıştr. Etkinliklerin uygulaması hafta içi pazartesi, çarşamba ve cuma sabah saat 10:00'da başlayıp saat 11:50'de bitmiştir. Her etkinliğin uygulama öncesi ve sonrasında 15'er dakikalık çocuklarla sohbet arası, oyun ve ihtiyaç molası verilmiştir. İki aylık uygulama sürecinde müdahale programının uygulandığı deney grubu çocuklarından birisi iki gün, bir diğer çocuk ise bir gün uygulamalara katılamamıştırlar. Uygulamaya katlan deney grubu çocuklarına SESFAR müdahale programı içerisinde yer alan etkinliklerin uygulama planları doğrudan öğretim modeline göre hazırlanarak uygulanmıştır. Sesbilgisel farkındalık pek çok çocuk tarafindan doğal bir şekilde edinilememektedir. Sözel dildeki bireysel sesler doğal dilde pek az duyulmakta ve duyuldukları zaman da, arkalarından gelen seslerden dolayı değişikliğe uğramaktadırlar. Okuma için gereken sesbilgisel farkındalık bilgisinin derinliğini çocu- 
ğun anlaması önemli olduğundan, sesbilgisel farkındalık eğitiminin doğrudan öğretimle yapılması önemlidir (Robinson, 2013). Smith ve diğerleri (2001) sesbilgisel farkındalık becerilerinin öğretiminde doğrudan öğretimin kullanılması gerektiğini vurgulamaktadırlar. Doğrudan öğretim, müdahalesi yapılan içeriğin; ardışık şekilde sıralanması, öğrencilerin tam katılımı, öğretmenin düzeltici dönütler vermesi, ipuçlarının düzenlenmesi, ipuçlarının uygulanması ve geri çekilmesi anlamına gelir (Güzel, 1998). Bu aşamada etkinliklerin doğrudan öğretim modeline göre nasıl uygulandığı açıklanmıştr.

Etkinliklere başlamadan önce uygulayıcı çocuklara o günkü etkinliklerin ne ile ilgili olduğundan bahsetmiş ve çocukların önceki bilgilerini harekete geçirmiştir. Etkinliğe ait materyallerin hazırlanmasında kullanılacak olan malzemeleri öğretmen sınıfa getirmiş ve öğretmen etkinlikte kullanılacak olan malzemeleri aynı anda tüm çocuklarla birlikte hazırlamıştır. Etkinlik için hazır olan materyaller ise çocuklara etkinlik kutuları içinde verilmiştir. Malzemelerin hazırlanmasının ardından etkinliğin uygulanış aşamasına geçilmiştir. Uygulama aşaması doğrudan öğretim modeli basamaklarına göre üç aşamadan oluşmaktadır. Birinci aşamada öğretmen çocuklara model olmak için etkinliğin nasıl yapılacağını bir örnek ile açıklamıştır. Bu aşamada öğretmen etkinliği ayrıntılı ve açık bir şekilde çocuklara anlatmıştı. Öğretmenin model olma aşamasında kullandığı görselleri öğretmen ve çocuklar kendi etkinlik kutularından çıkarmışlar ve uygulamaya dahil etmemişlerdir. Ardından ikinci aşama olan rehberli uygulama aşamasına geçilmiştir. Öğretmen burada çocuklarla birlikte etkinliği yapmaya başlamış ve bu aşamada çocukların etkin katılımı ile etkinliklerdeki rolünü öğretmen giderek azaltmıştır. Öğretmen çocuklara geri dönütleri bu aşamada vermiştir. Diğer bir aşama olan üçüncü aşama bağımsızlık aşamasıdır. Çocuklar burada etkinliği bağımsız olarak yapmışlar ve etkinlik bitene kadar bağımsızık aşaması devam etmiştir. Araştırmanın tamamı video kaydına alınmıştır. Araştırmada gözlemciler arası güvenirlik ve uygulama güvenirliği verileri analiz edilmiş ve yüksek güvenirlik bulguları elde edilmiştir.

\section{Veri Toplama Araçları}

Araştırma verilerinin toplanmasında bilgi formu ve EROT kullanılmıştır. Bilgi Formu; Çocuk Bilgi Formu ve Aile Bilgi Formu olmak üzere iki bölümden oluşmaktadır. İlk bölümde araştırmaya katılan deney ve kontrol grubunu oluşturan çocukların demografik bilgileri ve özellikleri hakkında bilgi toplamak için hazırlanmışken ikinci bölümde deney ve kontrol grubuna dahil edilen çocukların ailelerine ait özellikler hakkında bilgi edinmek için araştırmacı tarafindan hazırlanmıştır. Deney ve kontrol grubunda yer alan çocuklara ait toplanan özelliklerde çocuğun doğum tarihi, uygulamalarda yer alan bazı etkinliklerin yapılabilmesi için 1'den 7'ye kadar olan rakamları bilip bilmediği, daha önceden erken okuryazarlık becerileri ile ilgili eğitim alıp almadığı, herhangi bir yetersizliğinin olup olmadığı, daha önceden okulöncesine gidip gitmediği gibi bilgilere ulaşmak için oluşturulmuş bilgiler yer almakta iken deney ve kontrol grubunda yer alan çocukların ailelerinden toplanan bilgilerde ise anne ve babanın yaşı, eğitim durumu, sosyoekonomik düzeylerine ait bilgiler yer almaktadır.

EROT; Kargın, Ergül, Büyüköztürk ve Güldenoğlu (2015) tarafindan 60-72 ay arası çocuklarına yönelik geçerlilik ve güvenirlik çalışması yapılmış bir erken okuryazarlık testidir. Bu test erken okuryazarlık becerilerinin değerlendirilmesine ve risk grubunda yer alan çocukların belirlenmesine yönelik standart bir değerlendirme aracı olarak geliştirilmiştir. Bu amaçla geliştirilen EROT erken okuryazarlık becerilerini Alıcı Dilde Sözcük Bilgisi, Iffade Edici Dilde Sözcük Bilgisi, Genel İsimlendirme, İşlev Bilgisi, Harf Bilgisi, Sesbilgisel Farkındalık, Dinlediğini Anlama yedi boyutunda değerlendirmektedir. Araştırma kapsamında EROT değerlendirme aracının sesbilgisel farkındalık alt boyutuna ait değerlendirme bölümü kullanılmıştır. Sesbilgisel farkındalık becerileri sekiz alt test ile değerlendirilmektedir. Alt testlerin uygulanması sırasında öncelikle çocuklara uygun yönergeler verilmekte ve ardından da iki örnek madde çocuklarla birlikte yapılmaktadır. Sesbilgisel farkındalık becerilerine yönelik hazırlanmış olan alt testlere bakıldığında her alt beceride 2 örnek madde ve 4 soru maddesine yer verilmiştir. Sesbilgisel farkındalık becerilerine yönelik toplamda 16 örnek madde ve 32 soru maddesi yöneltilmektedir (Kargın, Güldenoğlu ve Ergül, 2015).

\section{Güvenirlik Verileri}

\section{SESFAR Gözlemciler Arası Güvenirlik Verileri}

Gözlemciler arası güvenirlik verilerinin elde edilmesinde bağımlı değişken için toplanan video kaydı kullanılmıştır. Toplanan video kayıtlarından yansız atama yolu ile seçilmiş olan bağımlı değişkene ait video kayıtlarının \%30 u iki bağımsız gözlemci tarafından kodlanmıştır. Kodlayıcılar arası güvenirlik "Görüş birliği / Görüş birliği + Görüş ayrılığı x 100" formülü (Kırcaali-iftar, ve Tekin, 1997) ile analiz edilmiştir. Sesbilgisel farkındalık becerilerine ait güvenirlik verileri Tablo 1'de gösterilmiştir. 
Tablo 1. Sesbilgisel Farkındalık Becerileri Güvenirlik Verisi

\begin{tabular}{lc}
\hline Madde & Tam Güvenirlik (\%) \\
\hline Sözcükleri Hecelerine Ayırma & 100 \\
Heceleri Birleştirme & 100 \\
Cümleyi Sözcüklere Ayırma & 100 \\
Uyak Farkındalığı & 100 \\
Son Sese Göre Eşleme & 100 \\
İlk Sese Göre Eşleme & 100 \\
Sözcüklerin Son Sesini Atma & 98 \\
Sözcüklerin İlk Sesini Atma & 100 \\
Toplam & 99.75 \\
\hline
\end{tabular}

Tablo 1'de kodlayıcılar arası güvenirlik \% 99.75 (ranj \% 98-100) olduğu görülmektedir. Bu oran bağımlı değişken için toplanan verilerin güvenilir olarak analiz edildiğine ilişkin bulgu sağladığını göstermektedir.

\section{SESFAR Uygulama Güvenirliği Verileri}

Araştırma boyunca çocuklara uygulanan bağımsız değiş̧en olan sesbilgisel farkındalık müdahale programı etkinliklerinin planlanan şekilde uygulanıp uygulanmadığını değerlendirmek amacı ile sekiz alt becerilerden rastgele seçilen videoların \%20'sinden uygulama güvenirliği verisi toplanmıştır. SESFAR müdahale programı uygulama güvenirliği formu ile toplanan verilerin analizi Tablo 2'de görülmektedir.

Tablo 2. Uygulama Güvenirliği Tarih ve Ortalamaları

\begin{tabular}{|c|c|c|c|c|c|c|c|c|c|c|c|c|c|c|c|c|c|}
\hline 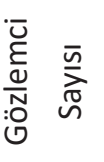 & 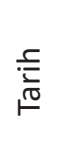 & 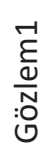 & 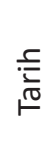 & 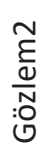 & 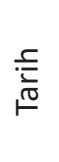 & 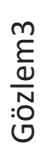 & 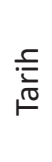 & 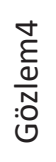 & 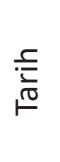 & 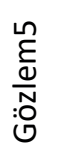 & 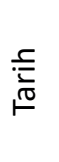 & 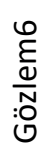 & 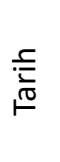 & 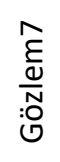 & 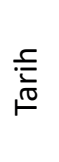 & 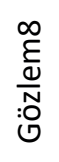 & $\begin{array}{l}\stackrel{\pi}{E} \\
\frac{\pi}{\pi} \\
\stackrel{T}{0} \\
0\end{array}$ \\
\hline 3 & 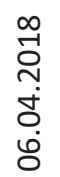 & $\begin{array}{l}\text { ô } \\
\text { o० }\end{array}$ & $\begin{array}{l}\stackrel{\infty}{0} \\
\stackrel{0}{+} \\
\dot{0} \\
\dot{y}\end{array}$ & $\begin{array}{l}8 \\
\text { 영 }\end{array}$ & 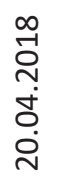 & $\begin{array}{l}\text { வீ } \\
\text { ㅇ }\end{array}$ & 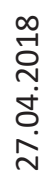 & $\begin{array}{l}\text { ठ } \\
\text { 우 }\end{array}$ & 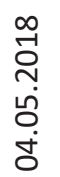 & $\begin{array}{l}\text { வீ } \\
\text { ㅇ }\end{array}$ & 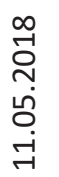 & $\begin{array}{l}\infty \\
\infty \\
a^{\circ}\end{array}$ & 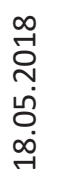 & $\begin{array}{l}\infty \\
\stackrel{\infty}{\circ} \\
\stackrel{0}{0}\end{array}$ & 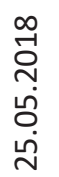 & $\begin{array}{l}8 \\
\text { 영 }\end{array}$ & $\begin{array}{l}\text { n } \\
\text { ஸू } \\
\text { ภ }\end{array}$ \\
\hline
\end{tabular}

Tablo 2 incelendiğinde 3 uzman tarafindan her bir haftada bir sesbilgisel farkındalık becerisine ilişkin video kayıtlarına göre yapılan analizler sonucunda uygulama güvenirlik ortalamasının \% 95.50 olduğu belirlenmiştir.

\section{Verilerin Analizi}

Bu araştırmada çalışma grubunun büyüklüğünün 10 olmasından dolayı nonparametrik istatistiksel teknikler veri analizi sürecinde kullanılmıştır (Kalaycı, 2014). Elde edilen verilerin analizinde 0.05 anlam düzeyine göre veriler yorumlanmıştir.

Zayıf Sesbilgisel Farkındalık Müdahale Programı öncesinde deney ve kontrol grubuna uygulanan öntest; uygulama sonrasında deney ve kontrol grubuna yapılan sontest puanları arasındaki farkı belirlemek amacıyla gruplar arası karşılaştırmalarda MannWhitney U Testi kullanılmıştır. Deney ve kontrol gruplarının grup içi öntest, sontest puanlarının karşılaştrılmasında Wilcoxon işaretli sıralar testi kullanılmıştır. Araştırmaya konu olan örneklem, iki durumda ölçülüyorsa, Wilcoxon işaretli sıralar testi kullanılabilir. Wilcoxon İşaret Testi testi aynı örneklem üzerinde önce ve sonra toplanan verilerin karşılaştıııması için kullanılan eşleştirilmiş t testinin (paired) non parametrik karşılığıdır. Wilcoxon işaretli sıralar testinde, veriler sürekli, bağımsız, rassal ve en az aralık (interval) ölçekle elde edilmiş olmalıdır (Kalaycı, 2014; Karagöz, 2010). Analizlerde bağımsız değişkenin (SESFAR) bağımlı değişken (sesbilgisel farkındalık becerileri) üzerindeki etki büyüklüğünü belirlemek amacıyla etki büyüklüğü ( $\eta 2$ ) değerinden faydalanılmıştr. Alanyazında "Eta kare" olarak da adlandırılan etki büyüklüğünün bağımsız değişkenin ya da faktörün bağımlı değişken üzerindeki toplam varyansın ne kadarını açıkladığını göstermekte ve 0.00 ile 1.00 arasında değer almaktadır (Kalaycı, 2014). 


\section{Bulgular}

Zayıf sesbilgisel farkındalık becerilerine sahip olan çocuklara uygulanan SESFAR müdahale programının sesbilgisel farkındalık becerileri üzerinde etkili olup olmadığı ile ilgili analizler iki başık altında incelenmiştir. Bunlardan ilki gruplar arası karşılaştırma, ikincisi ise grup içi karşılaştırmadır. Bulgular bölümünde ayrı başlıklar halinde yapılan analizler ve bu analizlerden elde edilen sonuçlar verilmiştir.

\section{Gruplar Arası Karşılaştırma}

Deney ve kontrol grubunun öntest ve sontest puanları arasında anlamlı bir farklılık olup olmadığını belirlemek amacıyla iki ayrı MannWhitney U Testi kullanılmıştır.

Tablo 3. Deney ve Kontrol Gruplarının Sesbilgisel Farkındalık Becerileri Öntest Mann Withney U Test Sonuçları

\begin{tabular}{lccccc}
\hline \multicolumn{1}{c}{ Gruplar } & N & Sıra Ortalaması & Sıralar Toplamı & Z & P \\
\hline Deney & 10 & 10,60 & 106,00 & & \\
Kontrol & 10 & 10,40 & 104,00 &,- 077 &, 938 \\
Toplam & 20 & & & & \\
\hline
\end{tabular}

Tablo 3' e bakıldığında deney ve kontrol grubunun sesbilgisel farkındalık becerileri öntest sıra ortalaması incelendiğinde deney grubunun sıra ortalamasının 10.60 kontrol grubunun sıra ortalamasının ise 10.40 olduğu görülmektedir. Grupların sıra ortalamaları arasındaki fark ise istatistiksel olarak anlamlı değildir ( $z=-, 077 ; p>0,05)$. Bu bulgu deney ve kontrol gruplarının uygulama öncesinde anlamlı bir farklılığa sahip olmadığını göstermektedir.

Tablo 4. Deney ve Kontrol Gruplarının Sesbilgisel Farkındalık Becerileri Sontest Mann Withney U Test Sonuçları

\begin{tabular}{lcccccc}
\hline \multicolumn{1}{c}{ Gruplar } & N & Sıra Ortalaması & Sıralar Toplamı & Z & P & n2 \\
\hline Deney & 10 & 15,50 & 155,00 & & & \\
Kontrol & 10 & 5,50 & 55,00 & $-3,801$ &, 000 & 0,965 \\
Toplam & 20 & & & & & \\
\hline
\end{tabular}

Tablo 4 incelendiğinde deney ve kontrol grubunun sesbilgisel farkındalık becerileri sontest sıra ortalaması incelendiğinde deney grubunun sıra ortalamasının 15,50 kontrol grubunun sıra ortalamasının ise 5,50 olduğu görülmektedir. Etki büyüklüğünün büyük etki oluşturduğu ve grupların sıra ortalamaları arasındaki farkın istatistiksel olarak anlamlı olduğu görülmektedir $(z=-3,801 ; p<0,01, \eta 2=0,965)$. Bu bulgu, deney grubuna uygulanan müdahale programının deney grubu çocuklarının sesbilgisel farkındalık becerilerinin gelişimine anlamlı düzeyde katkı sağladığını göstermektedir. Bu bulgu deney ve kontrol gruplarının uygulama sonrasında anlamlı bir farklılığa sahip olduğunu göstermektedir.

Tablo 5 incelendiğinde grupların öntest-sontest betimsel istatistik sonuçların bu bulguyu destekler nitelikte olduğu görülmektedir. Tablo 5'te gösterilmektedir.

Tablo 5 incelendiğinde; deney ve kontrol grubu çocuklarının öntest performanslarının betimsel istatistik sonuçlarına bakıldığında; deney grubunda yer alan çocukların öntest performans ortalaması $\bar{X}=13,10$; Medyanı 14,00; Standart Sapması 1,91; Minimum ve Maksimum değeri 10 - 15; Varyansı 3,65 ve ranj değeri ise 5'dir. Kontrol grubunda yer alan çocukların öntest performans ortalaması $\bar{X}=13,10$; Medyanı 14,50; Standart Sapması 3,10; Minimum ve Maksimum değeri 6 - 15; Varyansı 9,65 ve ranj değeri ise 9'dur.

Tablo 5' e bakıldığında; deney ve kontrol grubu çocuklarının sontest performanslarının betimsel istatistik sonuçlarına bakıldığında; deney grubunda yer alan çocukların sontest performans ortalaması $\bar{X}=29,90$; Medyanı 30,00; Standart Sapması 1,37; Minimum ve Maksimum değeri 27 - 32; Varyansı 1,87 ve ranj değeri ise 5 'dir. Kontrol grubunda yer alan çocukların sontest performans ortalaması $\bar{X}=13,50$; Medyan 14,50; Standart Sapması 2,79; Minimum ve Maksimum değeri 8 - 16; Varyansı 7,83 ve ranj değeri ise $8^{\prime}$ dir. 
Tablo 5. Deney ve Kontrol Gruplarının Sesbilgisel Farkındalık Becerileri Öntest-Sontest Performansları

\begin{tabular}{|c|c|c|c|c|c|c|c|c|c|c|c|c|c|c|c|c|c|c|c|}
\hline \multirow{2}{*}{ 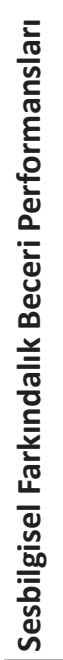 } & & \multicolumn{2}{|c|}{ 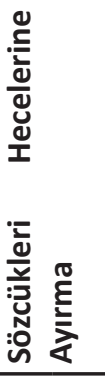 } & \multicolumn{2}{|c|}{ 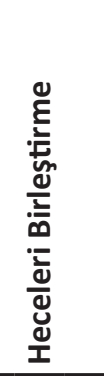 } & \multicolumn{2}{|c|}{ 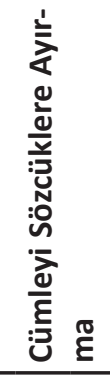 } & \multicolumn{2}{|c|}{ 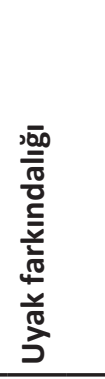 } & \multicolumn{2}{|c|}{ 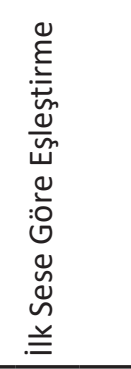 } & \multicolumn{2}{|c|}{ 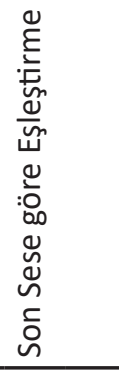 } & \multicolumn{2}{|c|}{ 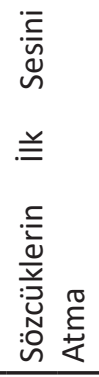 } & \multicolumn{2}{|c|}{ 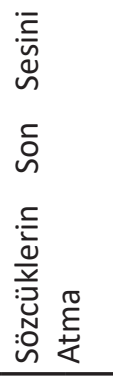 } & \multicolumn{2}{|c|}{ 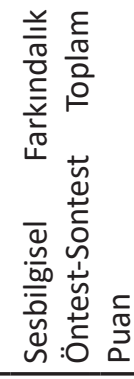 } \\
\hline & & $\begin{array}{l}\overrightarrow{\mathrm{J}} \\
\stackrel{\mathrm{J}}{\mathbf{L}}\end{array}$ & 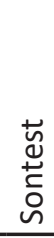 & $\begin{array}{l}\stackrel{+}{y} \\
\stackrel{ \pm}{ \pm} \\
: 0\end{array}$ & 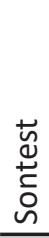 & $\begin{array}{l}\stackrel{艹}{\coprod} \\
\stackrel{ \pm}{t} \\
: 0\end{array}$ & 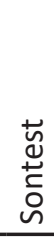 & $\begin{array}{l}\breve{y} \\
\stackrel{\Delta}{ \pm} \\
: 0\end{array}$ & 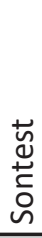 & 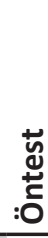 & 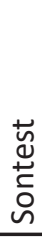 & $\begin{array}{l}\breve{d} \\
\stackrel{ \pm}{ \pm} \\
: 0\end{array}$ & 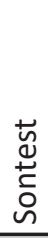 & $\begin{array}{l}\text { 岇 } \\
\stackrel{\text { ث̃ }}{0}\end{array}$ & 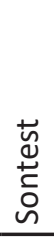 & 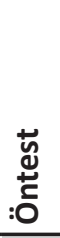 & 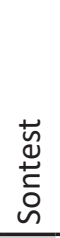 & 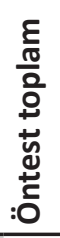 & 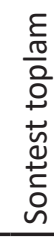 \\
\hline \multirow{10}{*}{ 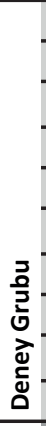 } & D1 & 4 & 4 & 3 & 4 & 1 & 4 & 3 & 4 & 1 & 4 & 1 & 4 & 0 & 3 & 0 & 2 & 14 & 29 \\
\hline & D2 & 4 & 4 & 4 & 4 & 0 & 4 & 2 & 4 & 1 & 4 & 1 & 4 & 0 & 4 & 0 & 3 & 12 & 31 \\
\hline & D3 & 4 & 4 & 3 & 3 & 1 & 3 & 2 & 4 & 3 & 4 & 0 & 4 & 0 & 4 & 0 & 4 & 14 & 30 \\
\hline & D4 & 4 & 4 & 1 & 4 & 0 & 4 & 2 & 4 & 2 & 4 & 2 & 3 & 0 & 2 & 0 & 2 & 11 & 27 \\
\hline & D5 & 3 & 4 & 2 & 4 & 2 & 4 & 1 & 3 & 3 & 4 & 3 & 3 & 0 & 4 & 1 & 3 & 15 & 29 \\
\hline & D6 & 4 & 4 & 4 & 4 & 3 & 4 & 3 & 3 & 1 & 3 & 0 & 4 & 0 & 4 & 0 & 4 & 15 & 30 \\
\hline & D7 & 4 & 4 & 3 & 4 & 1 & 4 & 1 & 4 & 2 & 4 & 3 & 4 & 0 & 4 & 0 & 4 & 14 & 32 \\
\hline & D8 & 4 & 4 & 4 & 3 & 0 & 4 & 3 & 4 & 2 & 4 & 2 & 4 & 0 & 4 & 0 & 4 & 15 & 31 \\
\hline & D9 & 3 & 4 & 3 & 4 & 0 & 4 & 3 & 3 & 0 & 3 & 2 & 4 & 0 & 4 & 0 & 4 & 11 & 30 \\
\hline & D10 & 2 & 3 & 2 & 3 & 2 & 4 & 2 & 4 & 2 & 4 & 0 & 4 & 0 & 4 & 0 & 4 & 10 & 30 \\
\hline \multirow{10}{*}{ 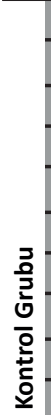 } & K1 & 3 & 3 & 0 & 2 & 2 & 2 & 1 & 1 & 0 & 0 & 0 & 0 & 0 & 0 & 0 & 0 & 6 & 8 \\
\hline & K2 & 3 & 3 & 3 & 2 & 1 & 2 & 1 & 1 & 0 & 1 & 1 & 0 & 0 & 0 & 0 & 0 & 9 & 9 \\
\hline & K3 & 4 & 4 & 3 & 2 & 1 & 2 & 3 & 2 & 1 & 1 & 1 & 1 & 0 & 1 & 0 & 0 & 13 & 13 \\
\hline & K4 & 4 & 4 & 4 & 4 & 2 & 2 & 3 & 3 & 0 & 1 & 1 & 1 & 0 & 0 & 0 & 0 & 14 & 15 \\
\hline & K5 & 4 & 4 & 3 & 4 & 2 & 3 & 2 & 1 & 3 & 2 & 1 & 1 & 0 & 0 & 0 & 0 & 15 & 15 \\
\hline & K6 & 4 & 4 & 1 & 0 & 2 & 3 & 3 & 3 & 3 & 2 & 2 & 1 & 0 & 1 & 0 & 0 & 15 & 14 \\
\hline & K7 & 4 & 4 & 4 & 2 & 0 & 3 & 3 & 2 & 2 & 1 & 2 & 2 & 0 & 1 & 0 & 1 & 15 & 16 \\
\hline & $\mathrm{K} 8$ & 4 & 4 & 4 & 3 & 3 & 2 & 3 & 3 & 0 & 0 & 0 & 2 & 0 & 1 & 0 & 1 & 14 & 16 \\
\hline & K9 & 4 & 4 & 4 & 4 & 2 & 3 & 2 & 2 & 1 & 1 & 2 & 0 & 0 & 0 & 0 & 0 & 15 & 14 \\
\hline & K10 & 4 & 4 & 3 & 4 & 1 & 2 & 3 & 4 & 1 & 0 & 2 & 1 & 1 & 0 & 0 & 0 & 15 & 15 \\
\hline
\end{tabular}

\section{Grup İçi Karşılaştırma}

Deney grubunun kendi içersinde öntest-sontest puanlarının karşılaştırılmasında iki farklı Wilcoxon işaretli sıralar testi kullanılmıştır. Deney grubunun öntest ve sontest puanları karşılaştııımış, analizden elde edilen bulgular Tablo 6'da verilmiştir.

Tablo 6. Deney Grubu Sesbilgisel Farkındalık Becerileri Öntest - Sontest Wilcoxon İşaretli Sıralar Testi Sonuçları

\begin{tabular}{lccccc}
\hline $\begin{array}{c}\text { Deney Grubu Öntest - } \\
\text { Sontest }\end{array}$ & N & Sıra Ortalaması & Siralar Toplamı & Z & P \\
\hline Negatif sıralar & 10 & 5,50 & 55,00 & & \\
Pozitif sıralar & 0 &, 00 &, 00 & $-2,825$ &, 005 \\
Eşit & 0 & & & & \\
Toplam & 10 & & & & \\
\hline
\end{tabular}

Tablo 6'da deney grubunun sesbilgisel farkındalık becerileri öntest-sontest sıra ortalaması incelendiğinde deney grubunu oluşturan çocukların sesbilgisel farkındalık becerileri öntest ve sontest ortalamaları arasında anlamlı bir fark bulunup bulunmadığını test etmek için yapılan wilcoxon işaretli sıralar testi sonucunda sıra ortalamaları arasındaki fark istatistiksel olarak $(p<0,01)$ düzeyinde anlamlı bulunmuştur. Söz konusu farkın kaynağı sontest lehine gerçekleşmiştir. 
Bu sonuç, müdahale programının deney grubunu oluşturan çocukların sesbilgisel farkındalık becerilerinin anlamlı biçimde arttı̆ını göstermiştir.

\section{Tartışma}

SESFAR, zayıf sesbilgisel farkındalık becerilerini desteklemeyi hedefleyen sekiz haftalık bir müdahale programıdır. Çalışma içerisinde SESFAR'ın etkililiğinin belirlenebilmesi için üç aşamalı bir süreç izlenmiştir. Bunlar; ön değerlendirme, müdahale ve son değerlendirme aşamalarıdır. Müdahale programının uygulamaya başlamadan önce ön değerlendirme aşamasında, her iki grupta (deney-kontrol) yer alan çocuklara EROT'un sesbilgisel farkındalık alt testi uygulanmış ve sesbilgisel farkındalık becerilerinin müdahale öncesinde deney ve kontrol grubunda yer alan çocuklarda benzer olması sağlanmıştr. Böylelikle deney ve kontrol grubu çocukları arasında müdahale sonrasında ortaya çıkabilecek farkın, uygulanan müdahaleden kaynaklı olup olmadığı belirlenebilmiştir. İkinci aşama müdahale aşamasıdır. Sonuçlar incelendiğinde, müdahale sonrasında yapılan son değerlendirmede iki grubun sesbilgisel farkındalık performansları arasında deney grubunun lehine anlamlı bir farklıık olduğu görülmüştür. Bu bulgu ise SESFAR'ın zayıf sesbilgisel farkındalık becerisine sahip olan çocukların sesbilgisel farkındalık becerisi gelişimleri üzerinde etkili olduğunu gösteren önemli bir bulgudur.

SESFAR, sesbilgisel farkındalık becerisi kapsamında dört temel alt boyutu temel alan bir müdahale programıdır. Bunlar; hece farkındalığı, kelime farkındalığı, uyak farkındalığı ve sesbirimsel farkındalık becerileridir. Alanyazında sesbilgisel farkındalık şemsiyesi altında yer alan bu becerilerin, çocukların ileride potansiyel okuyucular olmalarına zemin hazırlayan ve mutlaka erken çocukluk dönemi içerisinde kazanılmaları gereken temel okumaya hazırlık becerileri olduğu birçok çalışmada vurgulanmaktadır (Adams, 1990; Guimaraes ve Youngman 1995; Nielsen ve Luetke-Stahlman, 2002; Withrow, 2014). Yine konuya ilişkin yapılmış farklı çalışmalarda çocukların erken dönemde sahip oldukları sesbilgisel farkındalık becerileri ile ileriki okuma performansları arasında pozitif yönde anlamlı ilişkilerin olduğu sıkça belirtilmektedir (Ball ve Blacman, 1991; Foorman, Francis, Beeler, Winikates ve Fletcher, 1997; Lonigan, Purpa, Wilson, Walker ve Clancy-Menchetti, 2013; Torgeson, Wagner ve Rashotte, 1994). Bu görüşlerin benimsenmesi ile sesbilgisel farkındalık becerisi, özellikle uluslararası alanyazında erken okuryazarlık becerileri kapsamında ele alınan ve erken çocukluk döneminde en sık çalışılan beceri alanlarından biri olarak karşımıza çıkmaktadır. Uluslararası alanyazında çocukların sesbilgisel farkındalık performanslarını arttırmaya yönelik birçok müdahale programının geliştirildiği ve programların etkili sonuçlar verdiği farklı çalışmalardan elde edilen sonuçlarda görülmektedir (Blachman, Tangel, Ball, Black ve McGrow, 1999; Bryne ve Fielding-Barnsley, 1991; Guidry, 2003; Maslanka ve Joseph, 2002). Türkiye'de sesbilgisel farkındalık becerisine ilişkin yapılan çalışmalar incelendiğinde ise, çalışmaların genelinin son 10 yıllık dönemde gerçekleştirildiği ve bunların büyük bir çoğunluğunun da sesbilgisel farkındalık becerilerinin değerlendirilmesi boyutuna odaklandığı görülmektedir (Karaman, 2013; Kargın ve diğerleri, 2015; Sarı ve Aktan-Acar, 2013). Çalışmalardan elde edilen sonuçlara ayrıntılı olarak bakıldı̆ıında, Türk çocuklarının erken okuryazarlık becerileri kapsamında ele alınan sesbilgisel farkındalık becerilerinde beklenen yeterli başarıyı gösteremedikleri açıktır (Ergül, Karaman, Akoğlu, Tufan, Kesiktaş ve Kudret, 2014; Kargın, Güldenoğlu ve Ergül, 2017). Kargın ve diğerleri (2017) bu sonuçların iki temel noktadan kaynaklanmış olabileceğini belirtmişlerdir. Bunlardan ilki, okulöncesi programları içerisinde sesbilgisel farkındalık becerilerine ilişkin kazanımlara ait oluşturulmuş içeriklerin öğretmenlere bu becerilerin desteklenmesi konusunda yeteri kadar yol gösterici olamadığı, bir diğeri ise öğretmenlerin ve uygulamacıların sesbilgisel farkındalık becerilerinin öğretimi için etkili müdahaleleri oluşturma ve uygulamada yetersiz kalmalarıdır. Ayrıca öğretmenlerin sesbilgisel farkındalık becerisi öğretimine ilişkin sahip oldukları bilgi ve becerilerin yeterli düzeyde olmaması, özellikle okulöncesi öğretmenlerinin sesbilgisel farkındalık becerilerinin çocukların ileriki okuma ve okuduğunu anlama becerileri üzerinde ne derece ve nasıl etkileri olduğu ile sesbilgisel farkındalık becerisi ve okuma becerisi arasındaki ilişkinin düzeyi hakkında tam olarak bilgi sahibi olmadıkları (Deretarla-Gül ve Bal, 2006; Ergül, Karaman, Akoğlu, Tufan, Kesiktaş ve Kudret, 2014) ve bu nedenle de bu becerinin öğretimine yeterli önemi gösteremedikleri söylenmelidir. Bu açıdan bakıldığında çalışma içerisinde geliştirilen SESFAR öğretim programının özellikle sesbilgisel farkındalık becerisi öğretiminde alanda çalışan öğretmenlere rehber olabileceği ve bu yönüyle alandaki önemli bir boşluğu doldurabileceği düşünülmektedir.

SESFAR içerisinde önemli bir yer tutan ve alandaki öğretmenlerin desteklenmesi konusunda ciddi sınırlılıklar yaşadıkları alt alanlardan biri ise sesbirimsel farkındalık becerisidir. Sesbilgisel farkındalık kapsamında ele alınan bu beceri, sesbilgisel farkındalık becerilerinin ileriki okuma performanslarına yansımalarının görülebildiği önemli bir beceri alanı olup, bu yönüyle okumanın en temel yordayıcıları arasında önemli bir yer tutmaktadır (Heilmam ve Berman, 2013; Lundberg, Larsman ve Strid, 2012). Alanyazındaki çalışmalar incelendiğinde, sesbirimsel farkındalık becerilerinin temelde sesleri manipüle edebilme (ses atma, eşleme, ayırma, birleştirme vb.) becerilerinden oluştuğu ve bu becerilere yönelik yapılan etkili uygulamaların ise genelde okuma performansını özelde ise varolan sesbilgisel farkındalık performansını olumlu yönde etkileyeceği vurgulanmaktadır (Chiappe, Siegel ve Wade-Woolley, 2002; Jaskolski ve Moyle, 
2013; Liberman ve Shankweiler, 1991; Mercer ve Mercer, 2005; Wang, 1999). SESFAR içerisinde bu öneminden yola çıkılarak oluşturulan sesbirimsel farkındalık etkinliklerinin içeriği incelendiğinde, kapsam olarak çok çeşitli olduğu ve yukarıda belirtilen tüm sesbirimsel farkındalık alt becerilerine yönelik çalışmaları içerdiği görülmektedir. SESFAR'ın bu özelliği, özellikle öğretmenlerin sesbirimsel farkındalık becerilerini destekleme konusunda yaşadıkları tereddütleri ortadan kaldırmada ve konuya ilişkin etkili öğretim etkinliklerini üretmelerinde önemli olabileceği düşünülmektedir. Ayrıca SESFAR'ın sesbilgisel farkındalık becerilerinin tamamına yönelik farklı görseller ve etkinlikleri bünyesinde barındırması açısından sesbilgisel farkındalık becerilerine yönelik çok kapsamlı bir müdahale programı olduğu düşünülmektedir.

SESFAR etkinliklerinin, uygulama biçimi olarak doğrudan öğretim yöntemi benimsenmiştir. Doğrudan öğretim sesbilgisel farkındalık becerilerini edinimini doğal süreç içerisinde kazanamayan veya bir takım sesbilgisel farkındalık becerilerinin ediniminde zorluk yaşayan çocuklara hızlı ve etkili bir müdahale imkânı sunmaktadır. Sözel dildeki bireysel sesler doğal dilde pek az duyulmakta ve duyuldukları zaman da, arkalarından gelen seslerden dolayı değişikliğe uğramaktadırlar. Okuma için gereken sesbilgisel farkındalık bilgisinin derinliğini çocuğun anlaması önemli olduğundan, sesbilgisel farkındalık eğitiminin doğrudan öğretimle yapılması önemlidir (Robinson, 2013). Alanyazına bakıldığında, SESFAR müdahale programının uygulanmasında doğrudan öğretimin kullanılmasının gerekliliklerini arasında doğrudan öğretimin kısa zamanda, çok öğretim sunmak ve detayları kontrol altında tutma özelliğinin olması (Engelmann, Becker, Carnine ve Gersten, 1988) ve doğrudan öğretim modelinin küçük grup müdahalelerinde daha etkili olduğu vurgulanmaktadır (Becker ve Gernsten, 1982).

SESFAR etkinliklerinin, uygulama biçimi olarak doğrudan öğretim yöntemi benimsenmiştir. Doğrudan öğretim sesbilgisel farkındalık becerilerini edinimini doğal süreç içerisinde kazanamayan veya bir takım sesbilgisel farkındalık becerilerinin ediniminde zorluk yaşayan çocuklara hızlı ve etkili bir müdahale imkânı sunmaktadır. Sözel dildeki bireysel sesler doğal dilde pek az duyulmakta ve duyuldukları zaman da, arkalarından gelen seslerden dolayı değişikliğe uğramaktadırlar. Okuma için gereken sesbilgisel farkındalık bilgisinin derinliğini çocuğun anlaması önemli olduğundan, sesbilgisel farkındalık eğitiminin doğrudan öğretimle yapılması önemlidir (Robinson, 2013). Alanyazına bakıldığında, SESFAR müdahale programının uygulanmasında doğrudan öğretimin kullanılmasının gerekliliklerini arasında doğrudan öğretimin kısa zamanda, çok öğretim sunmak ve detayları kontrol altında tutma özelliğinin olması (Engelmann, Becker, Carnine ve Gersten, 1988) ve doğrudan öğretim modelinin küçük grup müdahalelerinde daha etkili olduğu vurgulanmaktadır (Becker ve Gernsten, 2001).

SESFAR, içeriği ve uygulanış biçimi itibariyle sesbilgisel farkındalık becerileri açısından desteklenmesi hedeflenen grubun yaş ve genel özelliklerine uygun olacak biçimde geliştirilmiş bir müdahale programıdır. Alanyazında özellikle okulöncesi dönem çocukları ile yapılacak uygulamalarda en etkili yolun oyun aracılığıyla öğretim olduğu ve bu çocukların yapılandırılmış masa başı etkinlikleri yerine daha doğal öğretim yöntem ve teknikleri ile desteklenmeleri sonucunda daha başarılı olabildikleri birçok çalışmada vurgulanmıştır (Callaghan, Mclvor, McVeigh ve Rushe, 2012; Carroll, Snowling, Stevenson ve Hulme, 2003; Nancollis, Lawrie ve Dodd, 2005). SESFAR ile desteklenmesi hedeflenen grubun da okulöncesi dönemdeki çocuklardan oluşması nedeniyle, SESFAR içerisinde, çocuklara kazandırılmak istenen hedeflerin onların ilgilerini çekebileceği düşünülen ve düzeylerine uygun oyunlar içerisine gömülmesine karar verilmiş ve tüm etkinlikler çocuklara oyunlar aracılığıyla sunulmuştur. Bu sayede çocukların daha eğlenceli ve keyifli vakit geçirebilecekleri, aynı zamanda da sesbilgisel farkındalık becerini destekleyebilecekleri ortamlar yaratılmaya çalışılmıştır. Ayrıca oyun odaklı etkinlikler çocukların sosyal yeterlilik gelişimlerini desteklediği gibi oyun sürecinde çocuklar birbirleri ile iletişim kurabilmekte ve var olan bir probleme birlikte çözüm önerileri getirebilmektedirler. Bununla birlikte SESFAR'ın bünyesinde oyun temelli etkinlikleri barındırması çocuklara neşeli ve rahat bir ortam sağlamakta, çocukta merak uyandırıcı ve farklı fikirleri görebildiği uygun ortamlar yaratmakta, sınıf içi standart uygulamaların dışına çıkarmaktadır. Bu sayede çocuklara kazandırılmak istenen bilgi ve beceriler daha ilgi çekici duruma gelmekte, çocuğun etkinlikler üzerine motivasyonu artmakta ve çocuklar eğlenirken öğrenmektedirler. Bu özelliği ise SESFAR'ın, önemli güçlü yanlarından biridir. Aynı zamanda bu özelliğiyle okulöncesinde etkili ve keyifli uygulamalar geliştirmek konusunda uygulamacılara olumlu bir örnek olabileceği düşünülmektedir.

Bu araştırmada bazı sınırlılıklarda bulunmaktadır. SESFAR müdahale programı hazırlanış şekli ile sesbilgisel farkındalık becerilerini kapsayıcı şekilde oluşturulmuştur. Fakat sesbilgisel farkındalık becerilerinden sesbirimsel farkındalık becerisine ait etkinlikler sözcüklerin ilk sesini eşleme, sözcüklerin son sesini eşleme, sözcüklerin ilk sesini atma ve sözcüklerin son sesini atma becerilerine odaklanmıştır. Sesbirimsel farkındalık becerileri içerisinde yer alan sözcükteki seslerin yerini değiştirme, aynı ses ile başlayan ve aynı son ses ile biten farklı sözcükler üretme becerilerine sesbirimsel farkındalık etkinlikleri içerinde yer verilmemiştir. Bu becerilerin etkinlikler içerinde yer almamasında Türkçenin saydam ortagrafik yapıda olması etkili olmuştur. Ayrıca bu becerilerin araştırma verilerinin elde edilmesinde kullanılan değer- 
lendirme aracı kapsamında ölçülemeyecek olması nedeni ile bu beceriler etkinliklere dahil edilmemiştir.

\section{Sonuç ve Öneriler}

SESFAR müdahale programının uygulama sonrasında EROT değerlendirme aracına göre yapılan son değerlendirmede deney grubunu oluşturan çocukların sesbilgisel farkındalık performansları lehine anlamlı bir farklılık olduğu görülmüştür. Sonuç olarak yukarıda sunulan tüm bilgiler birlikte düşünüldüğünde, SESFAR'ın sesbilgisel farkındalık becerilerinde desteğe gereksinim duyan çocukların, sesbilgisel farkındalık becerilerini desteklemede etkili bir program olduğu açıktr. İçerik ve kapsam açısından düşünüldüğünde, SESFAR, Türkiye'de bu konuda yapılmış ilk ve en kapsamlı müdahale programı olma özelliğine sahiptir. Aynı zamanda pratik, maliyeti düşük, kolay taşınabilir ve anlaşılabilir olması ile hem öğretmenler hem de aileler tarafindan gerek sınıf içinde gerekse de farklı ortamlarda rahatlıkla uygulanabilmektedir. Bu yönüyle Türkiye'de erken okuryazarlık becerilerinin öğretimi konusunda alandaki büyük boşluğu dolduracağı, öğretmenlere konunun öğretimine yönelik intiyaç duydukları desteği sağlayacağı ve Türkiye'de erken okuryazarlık becerilerinin desteklenmesi için önemli bir başlangıç noktası olacağı düşünülmektedir.

Ayrıca, SESFAR müdahale programı bir uzman tarafindan uygulanmıştır. SESFAR müdahale programının ailelere ve öğretmenlere öğretilmesi sesbilgisel farkındalık becerilerinin desteklenmesi, SESFAR müdahale programının araştırmacılar, aileler ve öğretmenler tarafindan daha sistematik olarak kullanılabilmesi için bilgisayar programı ve etkinlik kitapçıklarının hazırlanması, SESFAR müdahale programı etkinliklerinin genişletilerek farklı sözcük ve resimlerle uygulanmaSı, Zayıf sesbilgisel farkındalık becerilerine sahip çocuklara coşkulu, keyifli, bol ses efekti olan kitaplar okuyarak, seslere ait olan harfleri göstererek, evde ve sınıfta erken okuryazarlık köşeleri oluşturarak, alfabe şarkıları söyleyerek sesbilgisel farkındalık becerilerin gelişimine katkı sağlaması gerekmektedir. Ayrıca gerçekleştirilecek olan ileriki çalışmalarda SESFAR müdahale programı boylamsal çalışmalarda kullanılıp uzun dönemdeki etkilerine bakılabileceği gibi, gelecekteki araştrmalarda daha büyük örneklem grubu ile müdahale programının etkisine, SESFAR müdahale programı etkinlikleri doğrudan öğretim modeli ile uygulanmıştır. Yapılacak araştrmalarda etkinlikler farklı yöntem ve modeller kullanılarak doğrudan öğretim modeli ile uygulanan etkinlikler ile karşılaştıılarak etkisine bakılması önerile bilir.

\section{Kaynakça}

Adams, M.J. (1990). Beginning to read. Cambridge, MA: Harvard University Press.

Andreassen, M., and Simpson, R. (2008). Hierarchy of phonological awareness tasks.

Apel, K., and Lawrence, J. (2011). Contributions of morphological awareness skills to word-level reading and spelling in first-grade children with and without speech sound disorder. Journal of Speech, Language, and Hearing Research, 54(5), 1312-1327.

Ball, E. W., and Blachman, B. A. (1991). Does phoneme awareness training in kindergarten make a difference in early word recognition and developmental spelling?. Reading Research Quarterly, 49-66.

Becker, W. C., and Gersten, R. (1982). A follow-up of Follow Through: The later effects of the Direct Instruction Model on children in fifth and sixth grades. American Educational Research Journal, 19(1), 75-92.

Blachman, B., Tangle, D., Ball, E., Black, R. and McGraw, C. (1999). Developing phonological awareness and word recognition skills: A two-year intervention with low-income, inner-city children. Reading and Writing: An InterdisciplinaryJournal, 11, 239-273.

Byrne, B., and Fielding-Barnsley, R. (1991). Evaluation of a program to teach phonemic awareness to young children. Journal of Educational Psychology, 83(4), 451.

Bennett-Armistead, V. S., Duke, N. K. and Moses, A. M. (2005).Literacy and the youngest learner best practices for educators of children from birth to 5. USA: Scholastic Inc.

Callaghan, G., and Madelaine, A. (2012). Levelling the playing field for kindergarten entry: Research implications for preschool early literacy instruction. AustralasianJournal of Early Childhood, 37(1), 13-23.

Carroll, J. M., Snowling, M. J., Stevenson, J., and Hulme, C. (2003). The development of phonological awareness in preschool children. Developmental Psychology, 39(5), 913-923.

Carson, K. L., Gillon, G. T., and Boustead, T. M. (2013).Classroom phonological awareness instruction and literacy outcomes in the first year of school. Language, Speech, and Hearing Services in Schools, 44(2), 147-160.

Chiappe, P., Siegel, L. S., and Wade-Woolley, L. (2002). Linguistic diversity and the development of reading skills: A longitudinal study. Scientific Studies of Reading, 6(4), 369-400.

Daniel, M., and Reynolds, M. E. (2007). Phonological awareness instruction: Opinions and practices of educators and speech-language pathologists. Contemporary Issues in Communication Sciences and Disorders, 34, 106-117.

Demirel, Ö. (2014). Eğitimde program geliştirme. Ankara: Pegem A Yayıncılık.

Deretarla-Gül, E., and Bal, B. (2006). Anasınıfi öğretmenlerinin okuma yazmaya hazırlık çalışmalarına ilişkin bakış açıları, sınıf içi kullanılan materyal ve etkinlikler ile çocukların okuma yazmaya ilgilerinin incelenmesi. Çocuk Gelişimi ve Eğitimi Dergisi, 1(2), 33-51.

| Kastamonu Eğitim Dergisi, 27(6), 2019| 
Engelmann, S., Becker, W. C., Carnine, D., and Gersten, R. (1988). The direct instruction follow through model: Design and outcomes. Education and Treatment of Children, 11(4), 303-317.

Ergül, C., Karaman, G., Akoğlu , G., Tufan, M., Kesiktaş, D., and Bahap Kudret, Z. (2014). Okul öncesi öğretmenlerinin “erken okuryazarlık" kavramına ilişkin bilgi düzeyleri ve sınıf uygulamaları. Ilköğretim Online, 13(4), 1449-1472.

Foorman, B. R., Francis, D. J., Winikates, D., Mehta, P., Schatschneider, C., and Fletcher, J. M. (1997). Early interventions for children with reading disabilities. Scientific Studies of Reading, 1(3), 255-276.

Fox, N. P., Reilly, M., and Blumstein, S. E. (2015). Phonological neighborhood competition affects spoken word production irrespective of sentential context. Journal of Memory and Language, 83, 97-117.

Guidry, L. O. (2003). A phonological awareness intervention for at-risk preschoolers: the effects of supplemental, intensive smallgroup instruction (Unpublished Doctoral Dissertation). Louisiana State University, USA.

Guimãraes, A. S., and Youngman, M. (1995). Portuguese preschool teachers' beliefs about early literacy development. Journal of Research in Reading, 18(1), 39-52.

Güldenoğlu, B., Kargin, T., ve Miller, P. (2015). Okuma güçlüğü olan ve olmayan öğrencilerin cümle anlama becerilerinin incelenmesi.Türk Psikoloji Dergisi, 30(76), 82-96.

Güzel, R. (1998). Alt özel sınıflardaki öğrencilerin sesli okudukları öyküyü anlama becerilerini kazanmalarında doğrudan öğretim yöntemiyle sunulan bireyselleştirilmiş okuduğunu anlama materyalinin etkililiği (Yayınlanmamış Doktora Tezi). Gazi Üniversitesi, Ankara.

Heilmann, J., Moyle, M. J., and Berman, S. S. (2013). Assessment of early developing phonological awareness skills: A comparison of the preschool individual growth and development indicators and the phonological awareness and literacy screeningpreK. Early Education \& Development, 24(5), 668-686.

Jaskolski, J. E., and Moyle, M. (February, 2013). Effects of phonemic awareness training on early childhood educators' skills. Presentation at the Illinois Speech-Language-Hearing Asscociation Convention of Chicago, IL.

Johnson, K. L., and Roseman, B. A. (2003). The source for phonological awareness. East Moline, IL: Linguisystems, Inc.

Kahmi, A. G., and Catts, H. W. (2012).Language and reading disabilities. Upper Saddle River, New Jersey: Pearson Education, Inc.

Kalaycı, Ş. (2014). Spss uygulamalı çok değişkenli istatistik teknikleri. Ankara: Asi Yayıncılık.

Karaman, G. (2013). Erken okuryazarlık becerilerini değerlendirme aracının geliştirilmesi, geçerlilik ve güvenirlik çalışması (Yayınlanmamış Doktora Tezi).Gazi Üniversitesi, Ankara.

Kargın, T., Ergül, C., Büyüköztürk, Ş., ve Güldenoğlu, B. (2015). Anasınıfı çocuklarına yönelik erken okuryazarlık testi (EROT) geliştirme çalışması. Ankara Üniversitesi Eğitim Bilimleri Fakültesi Özel Eğitim Dergisi, 16(3), 237-268.

Kargın, T., Güldenoğlu, B., and Ergül, C. (2017). Anasınıfı çocuklarının erken okuryazarlık beceri profili: Ankara örneklemi. Ankara Üniversitesi Eğitim Bilimleri Fakültesi Özel Eğitim Dergisi, 18(01), 61-87.

Kırcaali-iftar, G., ve Tekin, E. (1997). Tek denekli araştırma teknikleri. Ankara: Türk Psikologlar Derneği.

Mann, V. A., and Liberman, I. Y. (1984). Phonological awareness and verbal short-termemory. Journal of Learning Disabilities, 17(10), 592-599.

Konza, D. (2011). Understanding the literacy process: Phonological awareness. Research into Practice, 1(2), 1-6.

Lane, H. B., Pullen, P. C., Eisele, M. R., and Jourdan, L. (2002). Preventing reading failure: Phonological awareness assessment and instruction. Preventing Reading Failure, 46(3), 101-110.

Liberman, I. Y., and Shankweiler, D. (1991). Phonology and beginning reading: A tutorial. In L. Rieben, and C. A. Perfetti (Eds.) Learning to read: Basic research and its implications (pp. 3-17). New Jersey: Erlbaum.

Lonigan, C. J., Purpura, D. J., Wilson, S. B., Walker, P. M., and Clancy-Menchetti, J. (2013). Evaluating the components of an emergent literacy intervention for preschool children at risk for reading difficulties. Journal of Experimental Child Psychology, 114(1), 111-130.

Lovelace, T. S. (2008). The effects of explicit phonological awareness instruction on the prereading skills of preschool children at risk for reading failure: Comparing single and multiple skill instructional strategies (Unpublished Doctoral Dissertation). The Ohio State University, USA.

Lundberg, I., Larsman, P., and Strid, A. (2012). Development of phonological awareness during the preschool year: The influence of gender and socio-economic status. Reading and Writing, 25(2), 305-320.

Mann, V. A., and Liberman, I. Y. (1984). Phonological awareness and verbal short-term memory. Journal of Learning Disabilities, 17(10), 592-599.

Maslanka, P., and Joseph, L. M. (2002). A comparison of two phonological awareness techniques between samples of preschool children. Reading Psychology, 23(4), 271-288.

Mercer, C. D., and Mercer A. R. (2005). Teaching students with learning problems (7th ed). Pearson Education, Inc.

Nancollis, A., Lawrie, B. A., and Dodd, B. (2005). Phonological awareness intervention and the acquisition of literacy skills in children from deprived social backgrounds. Language, Speech and Hearing Services in Schools, 36(4), 325-335. 
Nielsen, D. C., and Luetke-Stahlman, B. (2002). Phonological awareness: One key to the reading proficiency of deaf children. American Annals of the Deaf, 11-19.

Owens, R. (2005). Language development: an introduction (6th Edition). Boston: Pearson Education.

Paul, R. (2007). Language disorders from infancy through adolescence: assessmentand intervention (3rd Edition). St. Louis: Mosby Inc.

Robinson, S. A. (2013). Educating Black Males with Dyslexia. Interdisciplinary Journal of Teaching and Learning, 3(3), $159-174$.

Romero, A. (2015). Phonological awareness skills in first grade English language learners who speak Spanish and English (Unpublished Doctoral Dissertation). Murray State University).

Schatschneider, C., Francis, D. J., Foorman, B. R., Fletcher, J. M., and Mehta, P. (1999). The dimensionality of phonological awareness: an application of item response theory. Journal of Educational Psychology, 91(3), 439.

Scott, V. G. (2009). Phonemic awareness: Ready-to-use lessons, activities, and games. Corwin Press.

Smith, E. S. Skinner, C. H., and Cashwell, T. H., (2001). Increasing second-grade students' reports of peers' prosocial behaviors via direct instruction, group reinforcement, and progress feedback: A replication and extension. Education and Treatment of Children, 161-175.

Torgesen, J. K., Wagner, R. J., and Rashotte, C. A. (1994). Longitudinal studies of phonological processing and reading. Journal of Learning Disabilities, 27, 276-286.

Treiman, R. (1992). The role of intrasyllabic units in learning to read and spell. In P. Gough, L. Ehri, \& R. Treiman (Eds.) Reading acquisition (pp.65-106). Hillsdale, NJ: Erlbaum.

Wang, C. C. (1999). Learning to read Chinese: The roles of phonological awareness and morphological awareness (Unpublished Doctoral Dissertation). University of Illinois at Urbana-Champaign.

Withrow, K. (2014). Preschool teachers' understanding of phonological awareness (Unpublished Master Thesis).California State University, USA. 